\title{
Tobacco Networks in the Aegean Islands
}

\author{
Christos Bakalis \\ School of Social Sciences, University of the Aegean, Mytilene, Greece \\ Email: cbakalis@aegean.gr
}

Received 12 February 2016; accepted 11 April 2016; published 14 April 2016

Copyright (C) 2016 by author and Scientific Research Publishing Inc.

This work is licensed under the Creative Commons Attribution International License (CC BY). http://creativecommons.org/licenses/by/4.0/

(c) (i) Open Access

\begin{abstract}
The Aegean Archipelagos could be seen as a networked cultural space covered by multilevel web frameworks. The lines (flows or trajectories) are routes of people, goods, ideas and the nodes are the islands and their communities. At the same time islands are also fields of production that makes them matrixes of social and cultural creation. This paper deals with the cultivation and marketing of tobacco in the Aegean islands from the second half of the $19^{\text {th }}$ century to the end of the $20^{\text {th }}$ century. The presence of tobacco was combined with the transition to modernity for island communities when the capitalistic economy was spread and became dominant in the eastern Mediterranean. Following the division of labor, the tobacco processing reinforced the dependency of island economies from regional and global financial systems; also the establishment of an industrial working class within island societies. The tobacco left its mark in social and spatial formation in the Aegean islands both in urban and rural environments.
\end{abstract}

\section{Keywords}

Tobacco, Aegean Archipelagos, Islands, Networks, Culture, Transformation

\section{Introduction}

Between the years 1850 and 1950 the cultivation, processing and distribution of tobacco in the Aegean region were gradually developed. Its mass production started at the end of the 19th century, reached its peak in the first half of the 20th century and then, either willful abandoned by the farmers or was declined dramatically due to State's policies. Through the analytical study, it became obvious that the cultivation as well as the trade of tobacco in the Aegean islands, during the last two centuries, affected social and spatial structures and at the same time contributed to the economic, social and cultural transformation of the islands' communities. The rural life followed the rhythm of production, while urban populations lived in the pace of processing, manufacture and marketing of the product. The impact on rural and urban cultures was enormous and new symbolic spaces emerged. Although tobacco was never a monoculture, as it happened in other regions of the continental Greece, it left its stigma in the Aegean region. Today, the collective memory and the material culture, remind us an era 
of prosperity, when tobacco supported and formed local economies and societies. In addition, tobacco trading contributed dramatically to the islands' networks not only economically but also culturally in general, through webs of relations and contacts with offshore spaces. The discussion of the social and cultural impact of tobacco is directly connected to the study of the cultivation, processing and trade of the product. It became one of the main crops in Greece and was structurally connected to the economy and society. The modern history of tobacco could either be considered as an agricultural history, a workers' history, a trade networks' history also as a part of the industrial history. It is a history of national economies as well as a history of international financial networks. The circulation of tobacco enforced the monetization and the commercialization of the economy. It also developed regional contacts functioning as a catalyst towards the social and cultural transformation both in countryside and cities. In addition, the cultural study of tobacco is a part of the wider study for rural and urban spaces in Greece. Tobacco was not just one of the driving forces of local and national economy. Its role was multidimensional for rural areas and urban centers. The economic activity influenced the formation of social structures by a) developing professions, b) establishing merchants and industrialists and c) introducing a militant labor class. Moreover, various economic functions contributed to the spatial formation through the erection of workshops, factories and warehouses. Generally, it contributed to the social and spatial transformation of rural and urban places. Also financial and ideological networks had been developed within country, as well as between Greece and other countries.

The aim of this paper is to present the framework within which the presence of tobacco in the Aegean islands is progressively developed and later declined. It focused on the a) cultivation, b) processing and c) trade which took place from 1870s to 1960s. Data related to the above conditions are presented. The areas of interest are the large islands of the northeastern Aegean Archipelagos (Lesvos, Chios, Samos, and Lemnos). These islands are parts of the administrative region of North Aegean in east Greece. The northern island is Lemnos $\left(39^{\circ} 55^{\prime} \mathrm{N}\right.$ $25^{\circ} 15^{\prime} \mathrm{E}$ ), area $477 \mathrm{~km}^{2}$. Its population reaches 17,000 inhabitants. It is located $60 \mathrm{~km}$ from Athos peninsula in Chalkidiki (northwest), $100 \mathrm{~km}$ from Thracian coasts (north), $60 \mathrm{~km}$ from Dardanelles narrows (east), and 85 $\mathrm{km}$ from Lesvos (south). The capital town of Lemnos is Myrina. Lesvos is the biggest island in the north Aegean Sea $\left(39^{\circ} 10^{\prime} \mathrm{N} 26^{\circ} 20^{\prime} \mathrm{E}\right)$, area $1632 \mathrm{~km}^{2}$. Its population reaches 86,000 inhabitants. It is located 9 to $20 \mathrm{~km}$ from Asia Minor coasts (north and east) and $45 \mathrm{~km}$ from Chios (south). The capital city of Lesvos is Mytilene. Chios is the second largest island in the north Aegean Sea $\left(38^{\circ} 24^{\circ} \mathrm{N} 26^{\circ} 01^{\circ} \mathrm{E}\right)$, area $842,5 \mathrm{~km}^{2}$. Its population reaches 52,000 inhabitants. It is located 8 to $20 \mathrm{~km}$ from Asia Minor coasts (east) and $66 \mathrm{~km}$ from Samos (south). The capital city of Chios is Chios. Finally, Samos $\left(38^{\circ} 24^{\circ} \mathrm{N} 26^{\circ} 01^{\circ} \mathrm{E}\right.$, area $\left.476 \mathrm{~km}^{2}\right)$ is located only 1 mile from Asia Minor coasts (east). Its population reaches 33,000 inhabitants. The capital city is Vathy.

\section{World System and Regional Dependency in Modernity}

According to Immanuel Wallerstein ${ }^{1}$ the modern world system creates dependant relations between the capitalistic core and peripheries. These relations were particularly intense in the second half of the $19^{\text {th }}$ century. Metropolitan financial networks based on the division of labor were expanded upon Mediterranean basin and had major consequences in island and coastal populations. These networks connected local and global economies and societies. The Aegean islands were influenced radically from the development of international trade, and the investments which followed especially after tanzimat reforms in the Ottoman State. At that time (second half of the 19th century) Constantinople and Smyrna with the surrounding areas lost their significance as cores (within the framework of the state's economy) and were placed as peripheries in the framework of the western capitalistic economy ${ }^{2}$ ).

In such a dynamic environment there is no doubt that inequalities between core and peripheries became intense. The Aegean islands became parts of this relationship as peripheries receiving the effects and the influences of the western capitalism. Within this process local societies experienced the transition to wage labour and

\footnotetext{
${ }^{1}$ Wallerstein, I. 1974. The Modern World-System, vol. I: Capitalist Agriculture and the Origins of the European World-Economy in the Sixteenth Century, New York/London: Academic Press Wallerstein, I. 1980. The Modern World-System, vol. II: Mercantilism and the Consolidation of the European World-Economy, 1600-1750, New York: Academic Press Wallerstein, I. 1989. The Modern World-System, vol. III: The Second Great Expansion of the Capitalist World-Economy, 1730-1840's, San Diego: Academic Press.

${ }^{2}$ For Roderic H. Davison the reforms were undertaken in order to: “... to revitalize the empire and so to preserve it in a world increasingly ordered by European power and civilization. There was no aspect of Ottoman life that did not require change if this objective were to be attained". Davison, 1963. Reform in the ottoman empire 1856-1876, Princeton University Press. See also Faroqhi \& Adanir, 2002. "Introduction”, in Adanir, F. \& Faroqhi, S. (ed) The Ottomans and the Balkans: A Discussion of Historiography, Boston: Brill Academic Pub, pp $1-55$.
} 
modern means of production. In some cases industrialisation nocked the door of island communities and a new social class of entrepreneurs was appeared, undertaking roles of actors in the market economy both in local and regional level.

In certain Aegean islands the economic growth and mainly the growth of manufacture connected the local economies with the core of the capitalistic system through the expansion of various economic networks. A lot of investments took place in the islands pushing the local communities and administrations to create infrastructures and adopt new cultural forms. Gradually the port cities left their "traditional" picture and dressed with their modern costumes ${ }^{3}$.

Consequently the relation between core and periphery did not have only economic dimensions. The local cultures met the evolving western civilization. Perhaps the correct statement is that the local cultures were met with the western cultures in the framework of the Mediterranean cosmopolitanism ${ }^{4}$. In urban centres which constituted nodes of trade and distributers of products, mixed cultural elements were adopted initially by social elites. Increasingly the consumption of industrial products characterised the everyday life of residents in island cities and towns and gradually replaced the self-sufficiency that characterises the status of agrarian societies.

The new technologies were introduced also in communications. Telegraphy and steam ships reduced the time span of spatial distances. The industrial time replaced the agrarian one and the transition to modernity was gradually completed. The scientific developments which characterised the $19^{\text {th }}$ century led to the expansion of technological innovations. Even if the tobacco processing was based on the leaf selection by hand, technology impacted on the cigarette manufacturing also the creation of cutter machines for tobacco leafs.

\section{The Island Space in the Aegean Sea}

The Aegean Sea is a hypertext cultural space where vertical and horizontal relations connect different eras and geographies. During the large scale economical change cuts and continuities in time formed the elasticity of space. In addition, dynamic intercultural contacts shaped a framework for networking between people who lived in the area. As a Mediterranean subsection, it always carried key elements that characterize the whole basin. The different time scales (Braudel, 1995) become obvious through the study of the region. The islands always sought contacts with other places. During the last two centuries the geopolitical conditions in the region were instrumental in shaping the social, economic and cultural processes in general, creating cuts and sequels (transitions) in time and space. The islands and their societies, were affected by the dynamics and the transformations, and followed similar or even differed courses of development (Fasoulakis, 1998: pp. 329-338). Historical facts of major importance such as the emergence of nationalistic movements and the creation of nation states in Balkans ( $19^{\text {th }}$ century), also the dissolution of the Ottoman Empire, the Balkan Wars, the First World War and the Second World War ( $20^{\text {th }}$ century) left their mark on regional and local economies, societies and cultures. Certainly the island communities were crucially affected.

\section{Productive Structures in the Northeastern Aegean Islands}

Until the last decades of the $19^{\text {th }}$ century islands' economies in the Aegean Archipelago were based on agricultural production as well as on mercantile and shipping activities. In some cases the industrialization was already introduced in islands' port towns. Progressively, the circulation of products and commodities connected local economies to regional and global networks. Since tobacco became a major crop new trade connections were es-

\footnotetext{
${ }^{3}$ See Yerolympos, 2007. "New Patterns of Urban Development in the Aegean Islands, 1850-1920s” in Anna Frangoudaki, A. \& Keyder C. (ed) Was to modernity in Greece and Turkey: Encounters with Europe, 1850-1950, New York: Tauris, pp 236-257: “.....modernizing efforts in Greece and the Ottoman Empire had important spatial consequences for the urban settlements on the islands... similar changes took place in almost all the coastal cities of the eastern Mediterranean, as a result of the transition from the traditional medieval town to modern patterns of urban development" (p. 236) and "In the latter, after the adoption of the Tanzimat reforms in 1839, the granting of political and civil rights to all Ottoman subjects encouraged individuals, communities, and public institutions to adopt new economic and social behaviours and to invest in land and building. The physical restructuring of the cities became an essential aspect of the reforms" (p. 237).

${ }^{4}$ See Sifneos, 2005 “'Cosmopolitanism' as a feature of the greek commercial diaspora”, History and Anthropology, Volume 16, Issue 1 March 2005 , pp 97-111: "Cosmopolitanism indicates features of a common culture or lifestyle shared by entrepreneurial elites from different countries who self-consciously modeled themselves on the 'enlightened' perspectives of the industrial European metropolis. At Europe's periphery, this cosmopolitanism was characterized by greater freedom in the choice of models. The elites did not adopt particular national models, but mixed various elements of "European" culture: Paris and the rest of France were admired for its culture; London and the rest of England for its industrial strength, credit organization and merchant facilities; Germany for its organization and industrial dynamism; Italy for its architecture, music, and so on" (p. 102).
} 
tablished — sometimes stepping on old traces—and the peasants' life was changed. Concerning islands' productive structures there many differences which can be noticed. For example Lemnos lacked heavy industry. There, the processing of cereals (main agriculture product) was taken place in the windmills which were in function until the first decades of the $20^{\text {th }}$ century (Chtouris \& Bakalis, 2007; Bakalis, 2007) ${ }^{5}$. In Lesvos tens of investments in olive processing factories took place. The proximity to Asia Minor coasts was a key factor towards this development. After 1880 the enterprises grew gradually and the use of steam was expanded. Olive mills, soap factories and tanneries were built in Mytilene and elsewhere (Sifneou, 1996) ${ }^{6}$. In Chios, the dominant cultivation of mastic did not led to industrial development based on this product. In contrast, the manufacturing process was introduced and was associated with tanning. It should be noted that Chios had developed its commercial shipping and maintained strong ties with Greece (Athens and Syros). Moreover, apart from the mastic, the citrus were cultivated in central and south Chios. These two categories of products were covering the majority of island's export trade. Commercial networks with countries and regions such as India, Mesopotamia, Syria, Egypt, Turkey, Romania, Bulgaria, France, England, Germany (for mastic) and the Balkans (for citrus) were created (Sotiriades, 1936: pp. 274-282; Sotiriades, 1946a: p. 11) ${ }^{7}$. Samos was an autonomous periphery fact that shaped a different framework in local level considering the decision making conditions. Of course, the choices were affected by the developments in the wider region. Until the last decades of the $19^{\text {th }}$ century the island was dominated by the cultivation of vine without missing additional crops. The commercial networks send the Samian wine in destinations within Ottoman State, also Italy, Egypt, Germany and Romania. Likewise raisin was sold in Germany, Romania, England, France and Russia (Laiou, 2002: pp. 129-132; Melios, 1998: pp. 19-20). Finally, in Ikaria, the main cultivation was the vine. The raisin was exported to the nearby ports of Samos, Chios and Smyrni as well as to port cities of the Black Sea and the Balkans. Moreover, other agricultural crops, complemented the inhabitants' occupations (Yagourtas, 2004: p. 44; Melas, 1957: p. 154; Poulianos, 1976). From the last decades of the $19^{\text {th }}$ century, a new crop-tobacco-dominated many areas on both sides of the Aegean Sea.

\section{The Appearance of Tobacco in the Aegean Region in the 19th Century and Its Relation with Asia Minor and Greece}

The tobacco production and cultivation in the Aegean islands should not be seen separately from the cultivation of tobacco in regions of Asia Minor and continental Greece ${ }^{8}$. In the $19^{\text {th }}$ century and specifically after 1839 (beginning of Tanzimat reforms in the Ottoman State) the migration movements from the Aegean islands to coastal areas of the Asia Minor peninsula were increased. The main occupation of Greek orthodox farmers in villages in the wider area of Smyrna (including the regions of Ayvalik and Aydin) in the $19^{\text {th }}$ century was the production of raisin. Nevertheless, progressively they were engaged with the cultivation and production of tobacco. Moreover, since the tobacco circulation was officially controlled by monopoly policy, profitable smuggling activities were taking place, as it was happening with farmers in villages near Vourla of Erythrea ${ }^{9}$ (Anagnostopoulou, 1997: pp. 207-208). In Greece the tobacco cultivation and production were progressively increased from 1860 to 1889. After the raisin crisis (1889-1893), that impacted the Greek agriculture generally, the cultivation of tobacco was multiplied dramatically. Nevertheless, the large scale production and exportation took place after the Balkan Wars and First World War with the adaptation of Macedonia and Thrace in the Greek State (Dakin, 1989: p. 376).

\footnotetext{
${ }^{5}$ See also Belitsos, 1997; Belitsos, 1999: pp. 74-135.

${ }^{6}$ For the social transformation in Lesvos during the $19^{\text {th }}$ and $20^{\text {th }}$ century you can also see Chtouris $\&$ Varkaraki, 2000: pp. 27-101; Nickolakakis, 1997: pp. 125-36.

${ }^{7}$ See also Glykas, Rimikis, \& Skamalos, 1967: p. 24; Perris, 1972: pp. 85-86.

${ }^{8}$ The research for the tobacco in the Aegean region becomes very interesting due to the dimensions that it takes. Because of the multiple references that the tobacco had in the area, the researcher must rely on different islands and cities, where he or she can find data in archives and oral testimonies in order to document historical and cultural issues associated and connected even today with the tobacco cultivation, manufacturing and trade. This research started back in 2009. It aims to a cultural approach of the tobacco presence in the region. Very useful material is provided in newspaper collections in libraries such the Karatzadeios Library in Lemnos, the Public Library of Lesvos, the Public Library Korais of Chios and the Public Library of Samos. Alongside hundreds of publications on local history are contained in the above institutions. Furthermore, useful material is hosted in the departments of the General State Archives in the islands, especially in Mytilene and Samos. In Mytilene the archive of a tobacco merchant in the post-war period is well preserved. In Samos the huge archive of the Ephoria Kapnou (Tobacco Ephorate) provides ample evidence for the circulation of tobacco and its contribution to the relationships between the island and offshore places. In addition, useful documents are contained in the publications of the Cultural Foundation of Samos "Nicholaos Dimitriou".

${ }^{9}$ The opposite coast from Chios Island.
} 
The cultivation of tobacco in the territories of the Ottoman Empire-including Asia Minor-was established extensively in the $19^{\text {th }}$ century (Stravrides, 1996) ${ }^{10}$. Considering the islands, the available data convinces us that the cultivation started during the last decades of the $19^{\text {th }}$ century. It was the era, when the modernization and new technologies were introduced in the region. The railroad and steamships connected trade and industrial nodes creating networks of communication and transportation. In 1883 the Ottoman government introduced the monopoly of tobacco. The company which operated the monopoly was Regie (Société de la Régie cointéressée des tabacs de l'Empire Ottoman). The initial agreement between the Ottoman State and the company was for 30 years. Regie maintained the monopoly of production, storing and distribution (internal and external trade) paying an annual rental to the State. According to the agreement the cultivation was permitted in certain regions. In 1913 the contract was extended for an additional 15 years period ${ }^{11}$. At the same time the smuggling, which was a highly profitable activity, was increased. At the end of the $19^{\text {th }}$ century the cultivation of tobacco became a gainful occupation. Soon it attracted the interests of foreign investors and buyers. The production conditions were favorable. The dominant variety-Myrodata Smyrnis - did not need huge amounts of water resources while most of the islands lacked water deposits. In addition, dry fields offered higher quality tobacco (Kalitsounakis, 1931: p. 129) ${ }^{12}$.

The history of the Aegean islands' tobacco needs to be framed within the general economic and political conditions which characterized the status of the islands in the $19^{\text {th }}$ and the $20^{\text {th }}$ century. A periodically approach follows in order to make the above more specific.

\section{The Tobacco in the Aegean Islands}

Tobacco gradually became a global product exported and traded widely. Its impact on island communities was great as it happened with other regions of Greece (Bakalis, 2015: pp. 237-264). The needs and circumstances of cultivation and processing changed rural as well as urban environments in the Aegean islands. The effects on social structures were also important. A new labor class with a decisive role towards the formation of a strong union movement was created. The economy of tobacco influenced the everyday life of islanders through the formation of depended relations between domestic economies and global markets.

In the Aegean islands as well as in the rest of Greece, tobacco production was mostly a family-domestic matter. Nevertheless, according to farmers' oral testimonies, during the harvest, families supported each other. In the stage of processing in warehouses, a collective consciousness among workers was developed through common experiences and coexistence. Similarly, solidarity and mutual support between workers were formed. In economic level, farmers shaped relations with intermediaries and tobacco merchants. Tobacco became the mean that brought closer rural and urban population. In other words, it became the mediator between rural and urban culture, serving the connection between household economy and monetary economy in island rural communities at the end of the $19^{\text {th }}$ century and the beginnings of the $20^{\text {th }}$ century.

Each year in September (occasionally October) tobacco bales were concentrated for demonstration, evaluation and sale to merchants' representatives in central roads and squares of the villages. In coffeehouses farmers and representatives were met to make deals. There, antagonisms between representatives for the level of prices were taking place. On the other hand there was also hard competition between farmers for the level of quality of tobacco. The big warehouses of the port cities, where tobacco bales were transferred for processing, became symbols for the labor class. Soon, they were identified as places that signified the hard work conditions, the formation of labor consciousness and solidarity and the fields where workers' demands and demonstrations were expressed. With no doubt the arrival of new merchants and labor force (mainly refugees from Asia Minor) pushed to the creation of new economic and social dynamics in islands' port cities in the eastern Aegean Sea. The tobacco processing offered job positions to thousands of workers, also enrichment opportunities to hundreds of merchants (as well as commercial companies). Moreover, except the demographic increase and the spatial expansion of the cities (new workers' districts, big warehouses) a crucial benefit was the cultural growth for the island societies by welcoming new habitants also through contacts that were developed with other places following the routes of tobacco trade.

\footnotetext{
${ }^{10}$ It was cultivated in several provinces and regions from the Balkans, the Black Sea and Armenia to Syria and the Sinai Peninsula. Gradually it became one of the main cultivations beside vines, olives, cotton, grains and cereals.

${ }^{11}$ Nevertheless, after the establishment of the Republic of Turkey the Turkish State nationalized the company in 1925 and renamed it to Tekel.

${ }^{12}$ Besides, the use of chemical fertilizers was remained limited until the Interwar. The fields were divided into efficient and weak, depending on the soil’s quality. See also Karamina-Pothou, 1998: pp. 44-51; Jinakis, 1936: pp. 389-399.
} 
During the research for tobacco in the Aegean islands interviews with former tobacco farmers took place in villages in Lesvos (Aghia Paraskevi, Pamfila), Chios (Pyrgi, Kalamoti, Kini) and Samos (Mytilinii, Vathy). In most of the cases farmers remembered the years of tobacco cultivation as difficult and hard years. In cultivation and domestic processing all the family members were involved. In their words they described the conditions in the fields and their efforts to deal with merchants' representatives, trying to sale their harvest. They underlined the exploitation from mediators and merchants also their agony to sale their harvest as soon as possible in order to avoid stocking bales in their houses. Often the unsold stocked harvest was destroyed (burned). Nevertheless, they agreed that the economic importance of tobacco was great for their households helping them to raise their families. In addition, the profits were used to organize dowries for their children. Gradually, rural communities adapted their economies and way of living (including rhythms, organization labor conditions) to the demands of the tobacco production. In Samos, tobacco took the position of raisin (after the crisis of raisin production (1888-1890) and became the major crop; all the stages of the production (planting, harvest and marketing) changed farmers' lives. Starting in early spring and ending in late autumn, tobacco production was an occupation that centered farmers' attention for more than nine months per year. In the harvest season cultivators should maintain direct access to the plantations. Thus, most of the fields were close to settlements or else the farmers should spend enough time in farmhouses in the countryside. Progressively, in the Interwar years, cooperatives were organized aiming to ensure the farmers' interests.

The study of tobacco in the Aegean islands could be distinguished in three periods. The first period starts in 1870s and ends at 1912. It is related to the beginning of the systematic cultivation and the first attempts for processing and marketing. The second period, from 1912 to the mid- $20^{\text {th }}$ century, is related to the boom and the crisis in all stages of cultivation, production and circulation. Finally, the third period is related to the second half of the $20^{\text {th }}$ century and is characterized by the gradual abandonment and the expiry of the cultivation.

\section{The First Period: $19^{\text {th }}$ Century Until 1912}

In Samos the dominance of vineyards lasted until 1893, the year when the raisin crisis affected the island. The crisis was accompanied by social effects upon the rural population (Sariyannis, 1998: pp. 231-254) ${ }^{13}$. However, tobacco cultivation was familiar to the inhabitants before 1870. The introduction was made by Samians who were engaged with tobacco production in the opposite coasts of Asia Minor. From 1883 the production and the trafficking were outside the jurisdiction of the Regie's monopoly. The company tried to control the flow of traffic and benefit from the profits of trading. Nevertheless, such a plan did not succeed fact that allowed Samos to act without restrictions in the tobacco marketing. It should also be noted that alongside legal trading, the smuggling was widespread causing even small scale naval battles around the island between the Regie's staff and traffickers (Landros, 2002: pp. 111-128; Karamina-Pothou, 1998: pp. 37-47). In the 1890s the cultivation was expanded. Progressively the processing of tobacco leafs for handmade cigarettes, which were sold to Europe and even in China, Japan and South Africa, begun. In the early $20^{\text {th }}$ century Samian tobacco, was sold to factories in Egypt and European countries. In 1905, the economic prosperity of the island was visible (Haritatos \& Giakoumakis, 1997: p. 225). Several tobacco merchants started their enterprises. In the archival data some of them are presented as factory owners ${ }^{14}$. Well known merchants were A. Paschalis and Karathanassis Bros. who developed collaborations (exports) in European and African countries, Japan, China, Africa, India, Australia and New Zealand, England, America, USA and the Far East. Gradually, major investments in warehouses took place (Landros, 2007b; Diakoyannis, 1998: pp. 324-330). Alongside worker unions were established (Jichas, 2003: pp. 155-156). The tobacco workers constituted a new social class. In 1900 three hundred to four hundred families were depended on the tobacco industry (at least ten factories were operated). Beside Vathi (the capital town of Samos) the industries were also increased in Karlovasi (Jichas, 2003: p. 155; Landros, 2007a: p. 195).

In Chios, the systematic cultivation began in 1906 under the strict control of the Regie monopoly. According to the archival data, the harvests of 1906 and 1907 were sold to Manchester and those of 1908 to New York. The most productive villages were in south Chios (notiochora) where next to the mastic the tobacco was spread (Perris, 1971: pp. 34 and 62-64) $)^{15}$.

\footnotetext{
${ }^{13}$ In Mytilinie village riots took place resulted heavy casualties for protesters. See also Melios \& Bafouni, 2000: pp. 74-90; Vasilenas, 2003: pp. 66-73.

${ }^{14}$ Relative data in General State Archives in Samos, H $\Delta \Gamma$, Files Industry-Trade, 1882-1912.

${ }^{15}$ See also Madias, 1927: p. 15; Kokkalis, 1974: pp. 54-55; Eteria Limenos Chiou, 1946: pp. 110-168. The historical data includes statistics of tobacco imports and exports for the port of Chios, since 1909. Until 1912 the exports were increased progressively.
} 
Considering Lesvos, the cultivation was already taking place at least since 1886. Nevertheless, officially it was introduced after 1908 in central, western and northwestern areas of the island. In 1910 the production reached 30,000 oka and in the next two years 130,000 oka. In this period, the farmers were inexperienced and needed to learn the methods of cultivation. The used variety was Myrodata Samsudas (a variety from Samsun). The Regie monopoly tried to cut down smuggling and control the flows obligating the producers to use specific ports for the exports. The company maintained its central agency in the port area of Mytilene. In 1912 the local production reached 180,000 oka (Syrakis, 1913b: p. 5, 85-86) ${ }^{16}$. However the smuggling was in growth. Smugglers managed to maneuver by bribing the government offisers in local and regional level. The profits were huge and the base for this type of activity was the area around Ayvalik and Moschonisia (Enepekides, 1997: pp. 177-179; Koufopoulou \& Papageorgiou, 1997: pp. 153-171).

In Ikaria, the small tobacco production during the last years of the $19^{\text {th }}$ century was used for internal consumption. The cultivation was forbidden by Regie. The local authorities along with the authorities of the nearest islands Kalymnos, Patmos and Leros coordinated their efforts towards the free cultivation of tobacco. Finally, in 1905 the ottoman administration gave its consent for cultivation under the authorization of the Regie monopoly. However, the disagreements due to the actions of the company and the reactions on behalf of the ikarians continued to the point where the representatives of local authorities were arrested and taken into the prison in Chios Island. Eventually, after a new government's order the tobacco cultivation was free without the intervention of the Regie monopoly, which closed its office in Aghios Kirikos (Melas, 1957: pp. 206-221; Yagourtas, 2004: pp. 122-139).

In Lemnos there are travellers' reports for tobacco cultivation since 1858. In fact, a part of the production was exported. In 1889 the central plain of the island was dominated by corn, grapes and tobacco. Yet, the size of the cultivation was limited. Unfortunately analytical data was not found for the production conditions during this period (Tourptsoglou-Stefanidou, 1986: pp. 367, 444; Fraggelis, 2000: pp. 238-240).

Furthermore, at the end of the 19th century tobacco was cultivated in several Aegean islands. In Crete (small production in 1876) until 1912 trading and processing companies were established mainly in the two large cities: Chania and Heraklion. For Dodecanese there are no relative reports for widespread tobacco cultivations. In Rhodes and Kos, the free cultivation was finally allowed by the Ottoman administration in 1909. At the same period in Cyclades, Amorgos was one of the islands with small production that was partly bought by a dealer in Smyrna who represented a German factory in Hanover which was owned by a Greek capitalist. Moreover, Syros was a hub center for Greek, Bulgarian and Russian tobacco (Haritatos \& Giakoumakis, 1997: pp. 214, 335-374; Papastratos, 1964: p. 95) ${ }^{17}$.

\section{The Second Period from 1912 to 1950}

The period from 1912 to 1950 coincides with the rise and the crisis of cultivation, processing and marketing of tobacco in the Aegean islands. Within this period distinct sub periods can be defined, which were characterized by the impact of large scale historical events also specific policies that the Greek governments (Haritatos \& Giakoumakis, 1997: p. 215) ${ }^{18}$. Crucial events were the Balkan Wars that resulted in the adaptation of new regions (among them the north eastern Aegean islands) to the Greek State, the First World War, the war catastrophe for the Hellenic populations of Asia Minor peninsula, the effects of the Great Depression, the Second World War and the Greek civil war. Here, I will stand to the Asia Minor catastrophe and its overall impact on Greek geopolitics and local island life. The catastrophe was the end of a campaign of the Greek army after Veniselos' initiative based on the argument of State's expansion in lands where the population's majority was Greek. It started in 1919 and ended with the defeat of the army in 1922. After the war a population exchange took place between Greece and Turkey. About 1500.000 orthodox Christian citizens of Turkey moved to Greece from Asia Minor and East Thrace and approximately 500.000 Muslims citizens of Greece moved to Turkey. The impacts in Greece were tremendous in various levels. With the establishment of the new borders the geopolitics changed. Also the communication conditions for islanders were reorganized. For millenniums, since the Greek antiquity and the prehistoric years, the islands' residents had developed strong commercial and cultural bonds with the

\footnotetext{
${ }^{16}$ See also Paraskevaides, 1996: p. 165; Jimis et al. 1996: pp. 187 and 214.

${ }^{17}$ See also Stavrides, 1996: p. 9; Pantelides et al., 1909.

${ }^{18}$ In 1930, 28 from 331 tobacco companies in Greece were operating in islands. Twenty years later only 56 companies continued in major city centers of Greece. In the Aegean islands Samos and Lesvos maintained some enterprises.
} 
coasts of Asian Minor, making colonies and developing the trade as well. After 1922 the conditions were totally changed and the island populations were turned to the Greek mainland.

In Lesvos, from 1914 to 1923, the production and the value of tobacco were not stable. Specifically, in 1918 the number of the cultivated acres and the volume of production reached their peak. Afterwards, they were reduced until 1921. But again, things changed and the production rose until 1926 (Paraskevaides, 2006: p. 66). In Chios, the year of the great bend downwards for the production was 1921. In Samos, the bend downwards took place in 1920. In Cyclades, in the same year the cultivated lands were expanded and the production was raised. In Euboea, the peak year was 1919. In Crete, the production was low until 1923. Afterwards it was raised and reached its peak in 1925 (Melios \& Bafouni, 2000; Kalitsounakis, 1931: pp. 48-65).

\subsection{Processing-Marketing-Manufacturing-Networks (1912-1929)}

The marketing and processing of tobacco the years after the First World War (1919-1922) had begun to grow significantly in the large islands of the northeastern Aegean, as it happened in the rest of the country. The exports were stabilized with a large rise in 1922. Indicatively for the years 1919-1923 80 to 85\% of domestic production was exported to foreign countries. On the opposite the cultivation and the production showed a slight decline. Within the years 1919-1923 7.68\% of the total cultivated acres belonged to the Aegean islands (mainly the islands of the north-eastern Aegean Sea).Trade networks which linked islands with various destinations had begun to be established. American companies and Greek banks became buyers of local productions. Until 1918 the Greek tobacco was exported to Egypt, the USA, Italy, France and England. In the next two years the Netherlands (1919), Germany, Belgium and Austria (1920) were added (Argyros \& Mikelis, 1925: pp. 61-68).

At the outbreak of the First World War (1914) at least 50 factories and warehouses with 2,000 workers were operating in Samos. Half of the workforce was female, especially young women. There is not any convinced data found which can testify the impact of women workers to social spaces although women participated in strikes and demonstrations. Nevertheless, there are not strong evidences for female presence in worker's clubs, cafes etc. After the War the manufacturing of cigarettes followed a downward trend (while the processing of tobacco leaves was increased). In 1920 the number of merchants who expanded their activities in several countries in various continents was quite large. Steamers transferred the samian tobacco from the Vathy bay to Greek ports (mainly Piraeus and Thessaloniki) and ports abroad. Among several European destinations were Germany (Hamburg, Bremen, Dresden), Holland (Amsterdam, The Hague, Rotterdam), England, Norway (Bergen), Belgium, France (Marseille), Italy (Trieste), Romania (Konstatza) and Sweden. Furthermore, tobacco was sold in the USA (New York), the Far East (Shanghai), and in the nearby port city of Smyrni. All the sales were under the license of the Tobacco Ephorate and the State Tobacco Factory ('Kapnokoptirio') (Diakoyannis, 1998; Jichas, 2003: p. 157) ${ }^{19}$. Within the years 1920-1923 at least 28 merchants were collaborated with the State Tobacco Factory in Samos. Among the merchants and traders were the Bank of Athens, the National Bank of Greece, The Standard Commercial Trading of New York, the Glenn Tobacco Company INC, the Papastratos BROS, the Hermann Spierer company and dozens of local merchants such as A. Paschalis, M. Karathanasis, Soutos BROS, Nikolareizis \& Vlassopoulos, M. Metaxas, S. J. Stephanou M. Vogiatzoglou, L. Pialoglou and many others ${ }^{20}$. After the exclusion of Turkish tobacco from the USA markets during the First World War, the Greek tobacco-including the Samian-covered part of the needs in the USA. Nevertheless, the merchants' competition within the Greek State was heavy for the samian enterprises. Temporally, the correlations changed between 1920 and 1922 when Smyrni's tobacco was sold in international markets. Subsequent to the Asia Minor catastrophe and the burning of large stocks of tobacco in warehouses of the city in 1922, Samos became a regional center for the tobacco processing and trading (Haritatos, \& Giakoumakis, 1997: p. 225).

In Chios, more or less, imports and exports were rising with a temporary reduction in 1916 and a sharp drop in 1922. The impact of the war events was decisive for the trafficking of "cut" tobacco. Specifically, exports were limited while imports were increased. Among the destinations of exported tobacco leafs, (already from 1914), were Egypt, England, Austria and Germany (Eteria Limenos Chiou, 1946: pp. 110-168; Antonopoulos, K. 1914: pp. 57-67). In 1924, the tobacco was in the second position of the major products of the island following the mastic. A rapid increase in production and cultivation began in 1923 with the contribution of Asia Minor refugees who were expert growers. In 1924 the production exceeded 700 tones. Until the end of the year, 577

\footnotetext{
${ }^{19}$ See also Kalafatis, 1998: p. 36; Kalitsounakis, 1931: p. 28; Papastratos, 1964: p. 156-170; Bakalpmasis et al., 1930.

${ }^{20}$ Relative data in General State Archives in Samos, Archive of Tobacco Ephorate, Individual files of tobacco merchants $1920-1923$.
} 
tones were exported, valuing 15 million drachmas, while expectations for the total amount approached 20 million drachmas ${ }^{21}$.

At 1920 new tobacco merchants were recorded in Mytilene, Lesvos. Previously some of them were involved with other types of investment activities. However, since 1914 the A. Chiotellis family (with origins from Chios and Pergamos), owned already a strong processing, trading and industrial company (Haritatos \& Giakoumakis, 1997: pp. 342-363; Argyros \& Mikelis, 1925: p. 116). For Ikaria and Lemnos there is no data for systematic cultivation during the war decade 1912-1922. It should be noted that Lemnos experienced intense military presence of the Entente forces, when the island was used as a base for the war operations in Dardanelles narrows. The war conditions were not favorable for agricultural production.

Since 1922 and the disruption which caused by the defeat in Asia Minor front as well as by the uprooting of the population exchange that followed, the tobacco cultivation and trade followed rapid growth in Greece. Although the main producing regions were in continental Greece such as Macedonia, Thrace and Sterea Ellada, there are enough evidences which show that the cultivation was also developed in the islands. Since 1923-1924 large warehouses for the storage and the processing of tobacco were built in Samos (Vathy) and Mytilenie. The cutting machines and the cigarette machines were proliferated. Progressively the conditions for industrialized economies were strengthened. The tobacco workers were mainly newcomer refugees (with a significant presence of women), as it happened in many other regions of the country (Jichas, 2003: p. 159) ${ }^{22}$. In 1925 eighteen cigarette machines were operated in nine island cities (Argyros \& Mikelis, 1925: pp. 61-68): (Table 1).

In Vathy, tobacco merchants tried to restrict the refugees' move to other areas, due to the needs for labor hands in the newly built warehouses. In 1924, the number of female workers reached the 2,000 when men were counted to 500. Nevertheless, the union organization was not evolved at the same level as it happened in the case of the tanneries' workers in Karlovasi. In 1936 the tobacco workers' union "Anagennisis” was founded. In the previous year the Labor Center of Samos (Panergatikon Kentro Samou) was founded (Chatzimichali, 1998: p. 265 $)^{23}$. Refugees did not work only in the sections of processing and manufacturing. They were also employed in cultivation (Kolodny, 1972: p. 29) ${ }^{24}$. Tobacco warehouses were big buildings with two or three, even five floors. They exceeded 30 meters in length and 15 meters in width. During the Interwar they became landmarks in the changing urban space of the Vathi port. Specifically, within the years 1922-1934 the warehouses of G. Schutos, Nikolareizis \& Vlasopoulos, Herman Spierer, Loui Mark BROSS were built. In the 1930s the latest big tobacco warehouse was erected by Christodoulos Schutos (Diakoyannis, 1998) ${ }^{25}$. Besides Vathi, investments were made in Karlovasi where Stefanos Stefanou moved his factory (from Vathi). Occasionally (for example) in Schutos's warehouse part of the construction materials (timber) came from abroad.

Table 1. Cigarette machines in island cities (1925).

\begin{tabular}{ccc}
\hline City & Number of cigarette machines \\
Mytilene & 5 \\
Vathy & 1 \\
Chios & 1 \\
Syros & 1 \\
Chania & 1 \\
Rethymno & 1 \\
Heraclio & 1 \\
Aigina & 5 \\
Corfu & 1 \\
\hline
\end{tabular}

\footnotetext{
${ }^{21}$ Details for big businessmen in the island were not found. Nevertheless, there is a reference for a merchant named Stylianos Saltaris (Sotiriades, 1946a: pp. 7-16; Koufopantelis, 1935; Theotokas, 1935: pp. 28-33; Theotokas, 1936: pp. 246-252; Amantos, 1935: pp. 269-276; Diakoyannis, 1998).

${ }^{22}$ See also Diakoyannis, 1998; Karamina-Pothou, 2003: pp. 163.

${ }^{23}$ See also Diakoyannis, 1998; Landros, 2007b; Jichas, 2003: p. 156; Landros, 2007a; Drakos, 2003: pp. 149-153.

${ }^{24}$ As it happened in southern Chios, Lesvos and Lemnos. See also Petropoulos, 1935: p. 105; Jimis et al. 1996: p. 279.

${ }^{25}$ See also Haritatos \& Giakoumakis, 1997: pp. 226-236.
} 
Similarly, at least three large warehouses were built at that time in Mytilene, Lesvos (the biggest was Fridakis' warehouse). Apart from the new warehouses, many existing buildings were used for the tobacco processing. A characteristic case was this of an abandoned school for Muslim girls in the district Epano Skala. It was used by the company Chiotellis and Sons. Hundreds of female workers worked there, mainly refugee origin. For Chios evidences shows small-scale activities. This fact is confirmed by the limited exports of cut tobacco ("kekomenou kapnou”) as well as the recording of a small number of entrepreneurs (Haritatos \& Giakoumakis, 1997: pp. 339-356).

In Crete since 1915 many tobacco sellers and merchants in the prefectures of Chania, Heraklion, Rethymnon and less in Lasithi were recorded. In Chania a State Tobacco Factory was in function. Within next decades new companies were developed in the two major cities of the island (Igglesis, 1915: pp. 18-56) ${ }^{26}$. In Dodecanese islands (since 1912 they were annexed to Italy) the tobacco cultivation was also developed. There, the Italian Tabacchi Egei Manifattura Italiana became a monopoly company in the 1930s. It was the company which controlled the circulation of the product initially in Rhodes and Kos and afterwards in the rest of the Dodecanese islands. Syros and Euboea were two more islands in the Aegean Sea, where commercial activities were grown. Furthermore (in order to make a reference to the wider island environment and its relationship with the product), it must be labeled that companies also were operating in the Ionian Islands Corfu, Kefalonia and Zante (Haritatos \& Giakoumakis, 1997: pp. 277 and 336-373; Argyros \& Mikelis, 1925: pp. 64 and 115-116).

Generally after 1922 the export destinations did not change. Among them it was Trieste, which maintained infrastructures in warehouses for the collection of eastern tobacco. Until then the Greek State had not prepare timely infrastructures to Piraeus and Thessaloniki for the tobacco amounts (belonged to foreign companies) which were rescued from the Asia Minor catastrophe. Some of the companies which used warehouses in Trieste were: the American Tobacco Co of the Orient, the Cary Tobacco Company, the Hermann Spierer et Co and the Pavlidis company (Bakalmpasis et al. 1930: pp. 53-66; Kalitsounakis, 1931: pp. 28 and 78). In 1931, the ports of Samos and Mytilene were included to the major tobacco export ports of Greece alongside Kavala, Volos, Thessaloniki, Alexandroupoli, Piraeus, Patras and Nafplio. In Samos, the local tobacco merchant association was established. It was one of the eight tobacco merchant associations operated in Greece at that time (Kalitsounakis, 1931: p. 81) ${ }^{27}$.

\subsection{The Crisis and the Gradual Recovery (1929-1940)}

At the end of the 1920s, the tobacco cultivation was extended. Some villages of Samos turned almost exclusively to tobacco cultivation. Thus, for example, in 1930, Mytilinie (28\%), Ano Vathi (16\%), Chora (11\%), Neo Karlovasi (6\%), Palaiokastro (5\%) and Kokkari (4\%) gathered cumulatively $70 \%$ of the island's production. Overall, there were 36 villages where tobacco cultivation was recorded. The supremacy of Mytilinie village was overwhelming, as the village's production accounted 58\%, of the total production in Tigani periphery (Pythagorio), followed by the production of Chora (23\%).

In 1931 the number of tobacco farmers in the Greek islands stood 12,786, representing 9.72\% of the total number in the country. The cultivated acres summed 73,528, representing $8.27 \%$ of the total cultivated acres in the country. The production amounted to 2,879,758 kilos, representing $8.66 \%$ of the total production in the country. In the next year the farmers declined in 7210 (6.48\% of total), the cultivated acres reduced to 30,907 acres (4.4\% of total) and the production reduced to 1,087,892 kilos (5\% of the total) (Table 2).

Table 2. Total tobacco production in the Aegean island (1931, 1932).

\begin{tabular}{|c|c|c|}
\hline Farmers/areas/amounts & $\begin{array}{l}\text { Tobacco production in the } \\
\text { Aegean islands in } 1931\end{array}$ & $\begin{array}{l}\text { Tobacco production in the } \\
\text { Aegean islands in } 1932\end{array}$ \\
\hline Tobacco farmers in the islands & $\begin{array}{l}12,786 \\
9.72 \% \text { of the total number in the country }\end{array}$ & $\begin{array}{l}7210 \\
6.48 \% \text { of the total number in the country }\end{array}$ \\
\hline Cultivated acres in the islands & $\begin{array}{l}73,528 \\
8.27 \% \text { of the total cultivated acres in the country }\end{array}$ & $\begin{array}{l}30,907 \text { acres } \\
4.4 \% \text { of the total cultivated acres in the country }\end{array}$ \\
\hline Tobacco production in the islands & $\begin{array}{l}2,879,758 \text { kilos } \\
8.66 \% \text { of the total production in the country }\end{array}$ & $\begin{array}{l}1,087,892 \text { kilos } \\
5 \% \text { of the total production in the country }\end{array}$ \\
\hline
\end{tabular}

\footnotetext{
${ }^{26}$ See also Haritatos \& Giakoumakis, 1997: pp. 335-374; Argyros \& Mikelis, 1925: p. 115.

${ }^{27}$ Within the framework of this research, 29 folders of tobacco merchants and companies were located in the archive of Tobacco Ephorate for the years 1927-1928. Among them The American Tobacco Company of the Orient. The comparative study shows us that many companies were already active before 1922. In the years 1929-1930 the number was reduced to 23 (having obviously been affected by the crisis). General State Archives in Samos, Archive of Tobacco Ephorate, Individual files of tobacco merchants 1927-1928, 1929-1930.
} 
This decrease is attributed to a) the disappointment of the producers by the fact that much of the harvest of 1931 remained unsold, b) the drought of the summer of 1932 and c) the phasing out of the cultivation in areas with unsuitable soils; eventually the cultivation was forbidden permanent in 93 peripheries of the country (Serreos, 1933a: p. 4). In certain islands the effect of the crisis was catalytic. For example in Lemnos after the expansion of the cultivation in 28 villages (out of 32), finally it was forbidden in 1931 (Bakalis, 2007). In other cases where the cultivation continued, the reduction was visible in micro-level. For example, in Kini village in southern Chios the tobacco farmers were counted to 66 in 1924, been increased to 85 in 1928 and gradually reduced to 50 in 1932.

Moreover, in 1932, in the peak of the crisis, the image of the tobacco cultivation in each of the Aegean islands was the following ${ }^{28}$ : (Table 3).

The impact of the Great Depression occurred in trading. Until 1929 the marketing of tobacco in Samos followed an upward trend. Within the years 1927-1928 at least 29 merchants appealed to the State Tobacco Factory for their transactions. Afterwards, in the years 1929-1930 the number was reduced ${ }^{29}$.

During the interwar period, Samian as well as Lesvian merchants bought tobacco quantities from the nearest island of Chios (which lacked warehouses and processing factories). Between 1922 and 1929 the exports from the port of Chios had fluctuated. Afterwards, they rapidly declined. Thus, in 1936 the exports were accounted to 1/6 of the exports of 1929 (Eteria Limenos Chiou, 1946: pp. 110-168) ${ }^{30}$. In 1932 the Greek tobacco was exported to more than 30 different countries. First on the list was France, followed by Italy, Egypt and England. Among the exporters were the Samians M. Karathanasis, A. Paschalis and S. Stephanou; they exported the 4\% of the total amount of Greek exported tobacco (Serreos, 1933b: pp. 17-19). After the decrease of cultivation and production in the first years of the 1930s, a stabilization course was followed and later an upward trend. In Lesvos merchants and industrialists continued their activities, which were extended to continental areas ${ }^{31}$.

By the late of the 1930s and the outbreak of the Second World War, the historical course of tobacco in the Aegean islands should be treated as part of the overall development that the product [which was the most exported product (Injes, 1957: p. 14)] had in the whole country. In Greece the social and spatial structures were continuously transformed through the reforms of Venizelos' governments towards modernization, but also plagued by the big issue of rehabilitation and integration of the refugees. Islands became places for the first as well as for the final installation of a large number of refugees. Among the reforms an agricultural program that was started years ago, was applied after the refugees' arrival (Mouzelis, 1987: p. 91). This reform resulted in the elimination of big landownership, fact that functioned as a positive development for the industrial sector (Mouzelis, 1978: p. 92). Additionally, it included mechanization of crops and introduction of new banking institutions such as the establishment of the Agricultural Bank of Greece (Kalogirou, 1992: p. 88). At the same time cities' infrastructures were under continuous developing; introduction of electricity, construction of networks for water's distribution, new school buildings, modern cities' plans, new districts and settlements for refuges etc. But, the integration of refugees in Greece except economic and social dimensions had also cultural aspects. A labor

Table 3. Tobacco production in Lesvos, Chios, Samos, Cyclades, Euboea and Crete (1932).

\begin{tabular}{|c|c|c|c|c|c|c|}
\hline Farmers/areas/amounts & Lesvos & Chios & Samos & Cyclades & Euboea & Crete \\
\hline $\begin{array}{l}\text { Farmers (proportion in the total number of } \\
\text { the tobacco farmers in the Aegean islands) }\end{array}$ & $20.7 \%$ & $17.21 \%$ & $45.84 \%$ & $4.59 \%$ & $1.3 \%$ & $10.3 \%$ \\
\hline $\begin{array}{l}\text { Cultivations (proportion in the total } \\
\text { number of the tobacco cultivated } \\
\text { acres in the Aegean islands) }\end{array}$ & $29.26 \%$ & $9.09 \%$ & $40.9 \%$ & $3.42 \%$ & $0.8 \%$ & $16.47 \%$ \\
\hline $\begin{array}{l}\text { Production (proportion in the total tobacco } \\
\text { production in the Aegean islands) }\end{array}$ & $29.12 \%$ & $10.09 \%$ & $44.23 \%$ & $3.6 \%$ & $0.46 \%$ & $12.47 \%$ \\
\hline
\end{tabular}

\footnotetext{
${ }^{28}$ Serreos, 1933a: pp. 115-116.

${ }^{29}$ Relative data in General State Archives in Samos, Archive of Tobacco Ephorate, Individual files of tobacco merchants $1927-1928$ and 1929-1930.

${ }^{30}$ See also Vios, 1937: pp. 23-36; Sotiriades, 1946a; 1946b; 1946c; 1946d; 1946e; 1946f; 1946g; 1946h; $1946 \mathrm{i}$; Karousis, 1985 : p. 55.

${ }^{31}$ For example Menelaos Kardasos, in the years 1938-1939 has been interested for the tobacco production in the periphery of Ptolemaida. Among the information he had collected were names of villages, cultivated acres, production quantities, varieties, purchases of other merchants (potential competitors) with their values, and even the weather conditions in the region (relative data in General State Archives in Lesvos, ABE: Ф. 533. 2/1).
} 
culture was created in tobacco warehouses. The working class was organized in newly founded Unions and the union movement was strengthened. Women's position changed after their mass entrance in working spaces. In Mytilene and Vathi thousands of women worked in new built warehouses. On several occasions during the research collection, the individual and collective memory highlighted the significant and decisive contribution of refugees in all the stages of tobacco processing. The urban environments in the Aegean islands had been transformed by the development of processing and manufacturing of tobacco in the Interwar.

\subsection{The Second World War}

During the Second World War the commercial activities in Samos were interrupted. The tobacco stocks had been taken by the occupation forces (Haritatos \& Giakoumakis, 1997: p. 226) and the cultivation was limited to a minimum. In Chios, after the general pause that occurred in 1942, the local society lacked tobacco (Karousis, 1985: p. 55). Afterwards, in 1943, a limited number of farmers cultivated tobacco in the southern villages. During the Civil War some warehouses in Samos were used for the persecution of families of hunted rebels until the end of the conflict. In November of 1948 the DSE (Democratic Army of Greece) burned the State Tobacco Factory in Karlovasi (Vakaki-Moustaka, 2008: pp. 402-406; Thrasyvoulou, 2008: pp. 270-275). In the last years of the 1940s the tobacco production and processing were gradually restarted in the islands of the eastern Aegean Sea. Moreover, a new reality shaped after the war shock. Migration waves depopulated the Greek countryside. The island societies were losing their youth population.

\section{The Third Period: The Second Half of the Twentieth Century}

In the post-war years, many efforts towards the reorganization of tobacco cultivation were made in the Aegean islands, even if the conditions were unfavorable for further development and expansion. For various reasons in the 1950s the cultivation was declined gradually and was abandoned by the local communities (Lavrediadis, 1957: p. 15). However, just before the final withdrawal in the mid of 1960s the tobacco farmers in the Greek islands reached 7,000 while the total of the country was 193,000 (Vergopoulos, 1975: p. 253). The mass migration to major urban centers of the country, immediately after the Civil War, in accordance to the immigration abroad, weakened the rural population (Karamina-Pothou, 1998: pp. 58-59). In addition, after the Second World War the smoking habits had changed. American tobacco dominated smokers' preferences, fact that led to the decline of the need for samian tobacco (Haritatos, \& Giakoumakis, 1997: p. 226). By the early 1970s, the tobacco cultivation had progressively disappeared from Chios and Lesvos. The farmers had shifted to other crops (Pikile Ekdoseis, 1950: p. 35) ${ }^{32}$. In Samos, the cultivation in the postwar decades was also gradually declined. Some of the latest merchants were Schoutos, Voevodas and Afstroelliniki from Thessaloniki. In 1976 the number of tobacco farmers on the island was limited to 377. Half of them were from Mytilenie village. Even if new mechanical means were used for the preparation of the fields, the final abandonment came the 1980s when the Virginia variety became dominant in Greece. The cultivation in Samos ended in 1985 (Diakoyannis, 1998; Karamina-Pothou, 1998: pp. 61-62). Regarding to other islands, in 1962 6,025 acres were cultivated in Crete, 2,235 acres in Dodecanese and only 387 acres in Cyclades ${ }^{33}$. In Rhodes, the Rodian Tobacco Manufactures, a tobacco export company in international trade, suspended its operations in late 1973 (Hellenoaraviko Emporiko Epimelitirio, 1958: p. 322 $)^{34}$. In the late $20^{\text {th }}$ century (1991), only eight cultivations were officially recorded in the Aegean islands from a high of 60,764 in Greece. Totally they covered an area of forty acres. Three cultivations in Dodecanese (29 acres), one in Lesvos ( 3 acres), one in Chios ( 1 acre), one in Rethymno (1 acre) and one in Chania (1 acre). A few years later, 44 acres were cultivated in Atsiki Lemnos (virginia variety) ${ }^{35}$.

\section{Conclusion}

Concluding, the research for the history and the culture of tobacco in the Aegean Archipelago is a part of the study for rural and urban spaces in the region. The economic activities which were related to tobacco influenced the formation of social structures in island societies. New professions, new merchants and a new labor class were introduced. Generally, the tobacco was a catalyst for social and spatial transformation of the places where

\footnotetext{
${ }^{32}$ See also Matzaroglou, 1963: p. 108; Glykas, Rymikis \& Skamalos, 1967: pp. 32 -34 and 58; Tragelis, 1999: p. 64; Kralis, $1963:$ p. 173.

${ }^{33}$ Relative data in General State Archives in Lesvos ABE: Ф. 533. 1/121.

${ }^{34}$ See also Papachristodoulou, 1994: pp. 18-19; Haritatos \& Giakoumakis, 1997: pp. 373-374.

${ }^{35}$ Relative data in Hellenic Statistical Authority.
} 
it appeared. Its networks became parts of wider systems which connected islands with other places. In a comparative perspective, the case study of the impact of tobacco cultivation and production in island spaces offers the chance to illuminate the specific nature of island economies and communities. The introduction and the adaption of tobacco cultivation from outside can show the sensitivity of island systems as well as the depended economic, social and cultural relations with other places. Certainly, the study of tobacco in the Aegean islands is not limited to aspects of economic and social history. It is related to the cultural history of the islands. The impact on the way of living, ideas and social acting was critical. Moreover, tobacco functioned vitally as a mean for the relations and contacts between island communities and the outside world.

\section{Acknowledgements}

Thanks are due to Christos Landros and the staff of General State Archives in Samos, Telavges Demetriou and Matrona Ktistou in the Cultural Foundation of Samos "Nikolaos Dimitriou”, Aristea Koufopanteli and the staff of the Koraes Central Public Library of Chios, Costas Moniodis in the village Kini of Chios, Katerina Karayannopoulou and the staff of the General State Archives in Lesvos, Malama Rentari and Christina Varkaraki in the University of the Aegean and the staff of the Central Public Library of Mytilene.

\section{References}

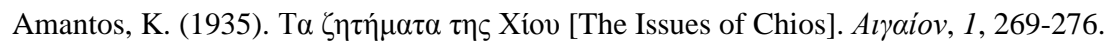

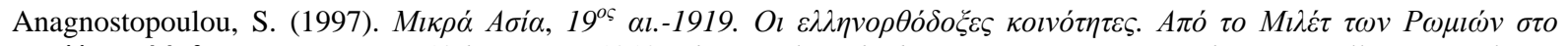

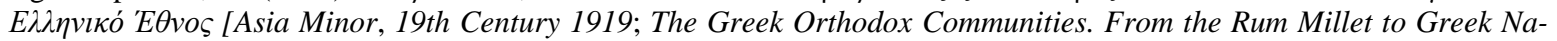
tionhood]. Athens: Ellinika Grammata.

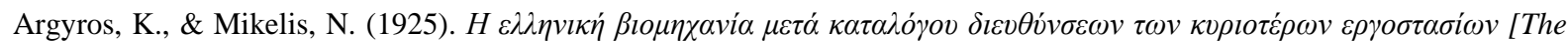
Greek Industry with an Address Catalogue of Major Factories]. Athens: Ministry of National Economy, Administration of Trade and Industry, The National Printing House.

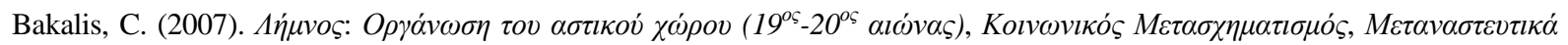

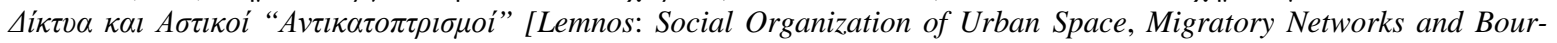
geois Reflexes in Lemnos Island during the 19th and 20th Century]. PhD Thesis, Mytilene: University of the Aegean.

Bakalis, C. (2015). The Impact of Tobacco in Greece (Cultivation, Processing, Manufacturing, and Trade). In F. Jacob, \& G. Dworok (Eds.), Tabak und Gesellschaft, Von braunen Gold zum sozialen Stigma (pp. 237-264). Baden-Baden: NOMOS.

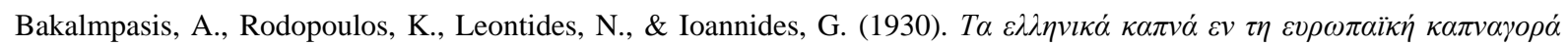
[The Greek Tobacco in the European Tobacco Market]. Athens: The National Printing House.

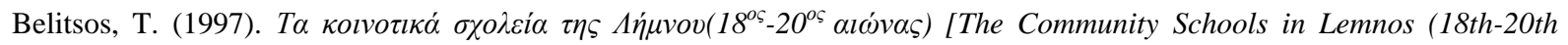
Century)]. Athens: Syllogos pros Diadosin Ofelimon Vivlion.

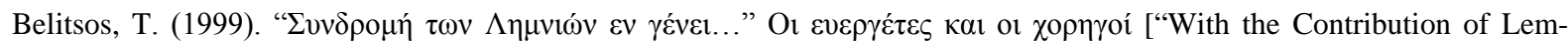

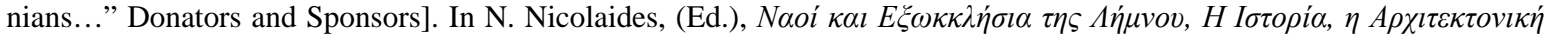
$\kappa \alpha \iota ~ \eta \Delta \imath \alpha \kappa o ́ \sigma \mu \eta \sigma \dot{~} \tau o v \varsigma$ [Churches and Chapels of Lemnos, History, Architecture and Decoration] (pp. 74-135). Athens: Eteria Archipelagous, Nea Synora-Livani.

Braudel, F. (1995). The Mediterranean in the Age of Philip II. London: University of California Press.

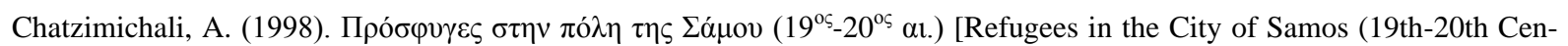

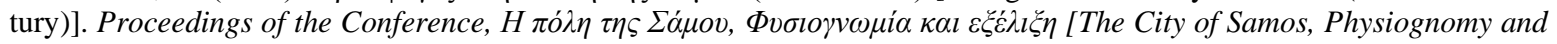
Evolution], Samos, 9-11 May 1997, 253-278.

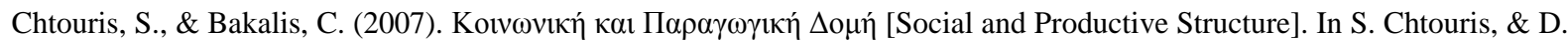

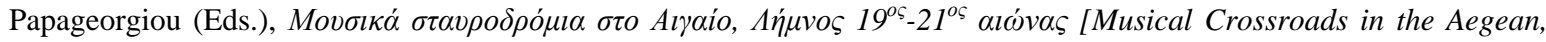
19th-21st Century] (pp. 47-180). Athens: ION.

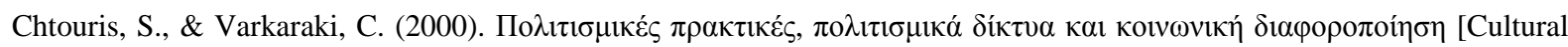

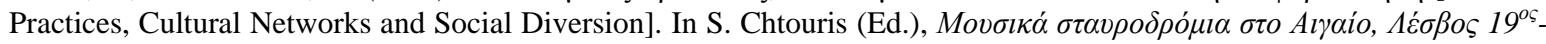
$20^{\circ \varsigma}$ al ́vas [Musical Crossroads in the Aegean (19th-20th Century)] (pp. 27-101). Athens: Exantas.

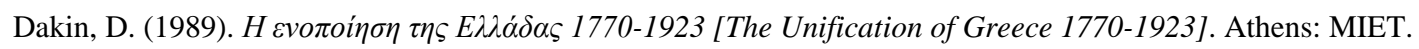

Davison, R. H. (1963). Reform in the Ottoman Empire 1856-1876. Princeton, NJ: Princeton University Press.

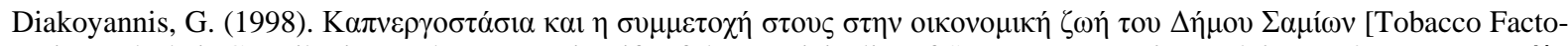
ries and Their Contribution to the Economic Life of the Municipality of Samos]. Proceedings of the Conference in H $\pi \dot{\lambda} \lambda \eta$

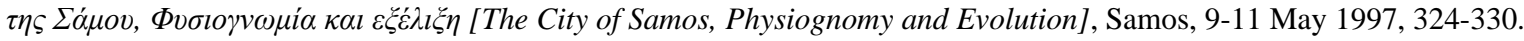




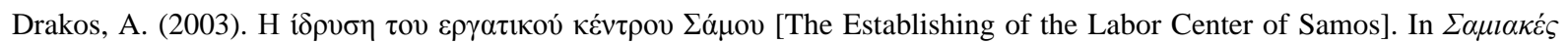

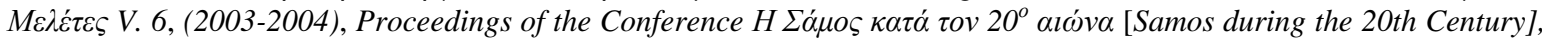
Samos, 10-12 November 2000 (pp. 149-153). Athens: Cultural Foundation of Samos "Nicholaos Demetriou”.

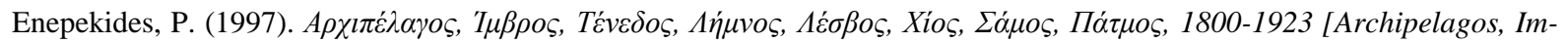
vros, Tenedos, Lemnos, Lesvos, Chios, Samos, Patmos, 1800-1923]. Athens: Estia.

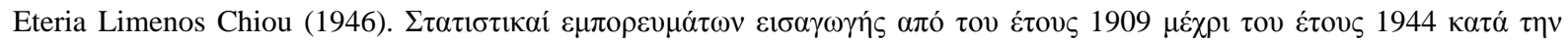

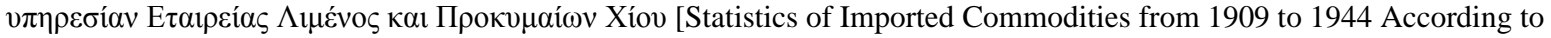

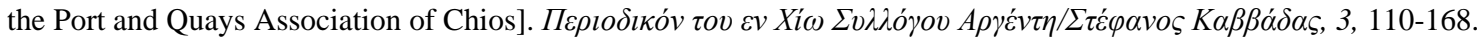

Faroqhi, S., \& Adanir, F. (2002). Introduction. In F. Adanir, \& S. Faroqhi (Eds.), The Ottomans and the Balkans: A Discussion of Historiography (pp. 1-55). Boston, MA: Brill Academic Pub.

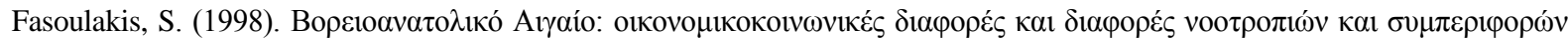

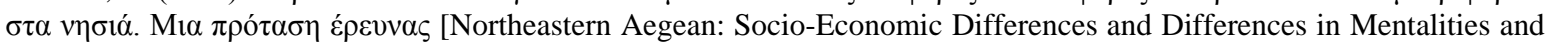

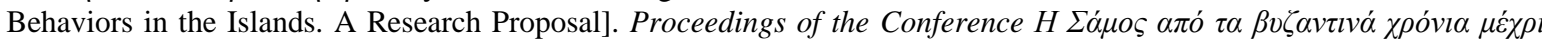
$\sigma \eta \dot{\mu \varepsilon \rho \alpha}$ [Samos from the Byzantine Years up Today], Vol. 2, Samos, 28-30 April 1995, 329-338.

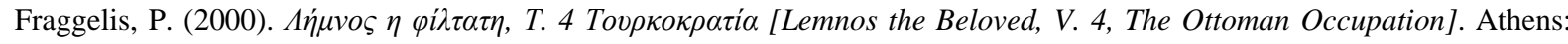
Elefthery Skepsis.

General State Archives in Lesvos, ABE: Ф. 533. 2/1, Ф. 533. 1/1, 9, 10, 11, 23, 25, 26, 30, 121.

General State Archives in Samos, Archive of the Tobacco Ephorate, Individual Files of Tobacco Merchants 1920-1923, 19271928, 1929-1930, 1945-1963.

General State Archives in Samos, H $\Delta \Gamma$, Files Industry-Trade, 1882-1912.

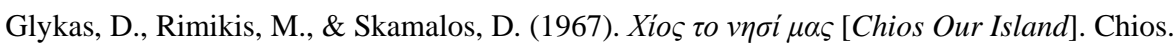

Haritatos, M., \& Giakoumakis, P. (1997). A History of the Greek Cigarette. Athens: ELIA.

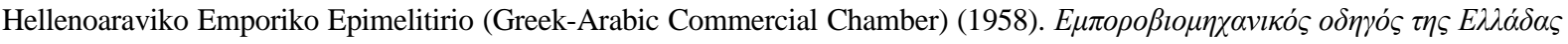

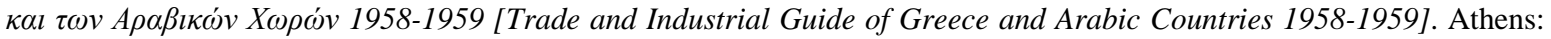
Greek-Arabic Commercial Chamber.

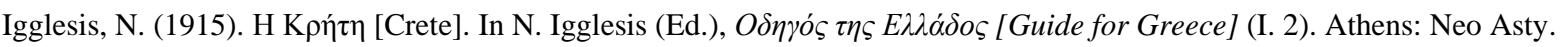

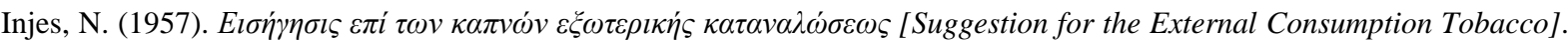
Greek Parliament, Period D, Synod B, Committee for Tobacco Issues, Athens: The National Printing House.

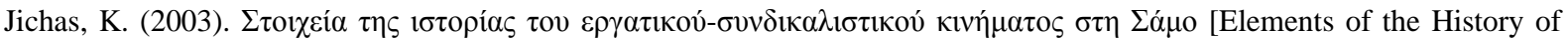

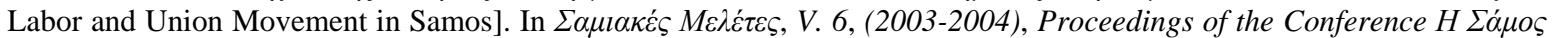

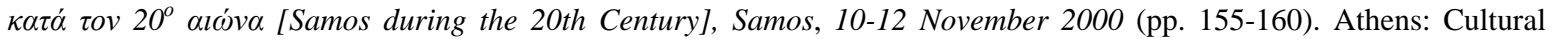
Foundation of Samos "Nicholaos Demetriou".

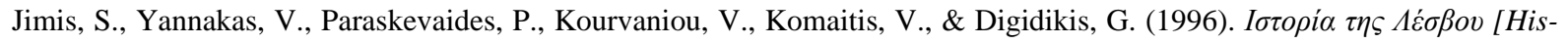
tory of Lesvos] (2nd ed.). Mytilene: Syndesmos Filologon Lesvou.

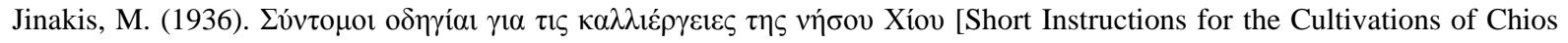

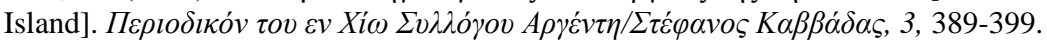

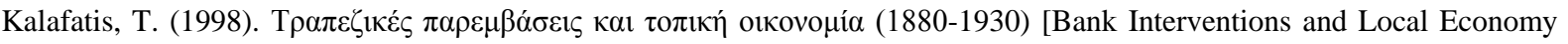

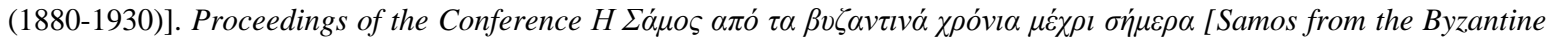
Years up Today], Vol. 2, Samos, 28-30 April 1995, 25-41.

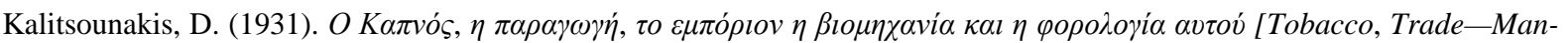
ufacture-Taxation]. Athens: Estia

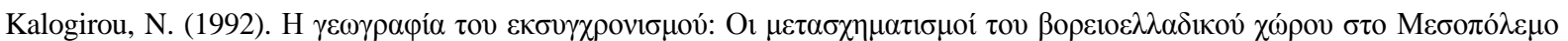
[The Geography of Modernization: Transformations in North Greece in the Interwar]. In G. Mavrogordatos, \& C. Chatzii-

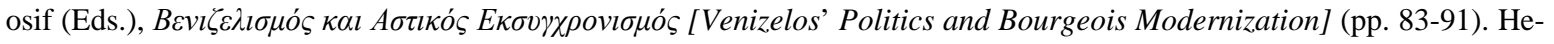
raklio: Univercity of Crete Press.

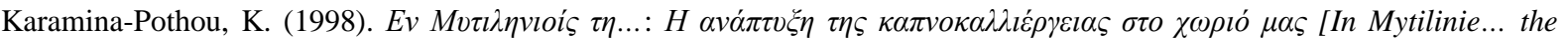
Growth of Tobacco Cultivation in Our Village]. Samos: Pnevmatiko-Politistiko Kentro Kinotitas Mytilinion.

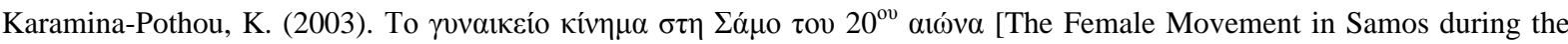

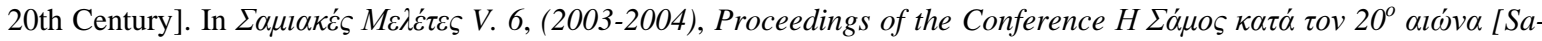
mos during the 20th Century], Samos, 10-12 November 2000 (pp. 161-170). Athens: Cultural Foundation of Samos "Nicholaos Demetriou".

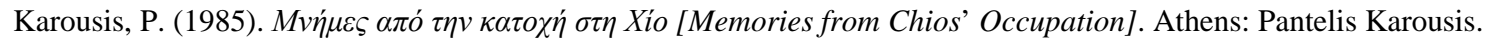




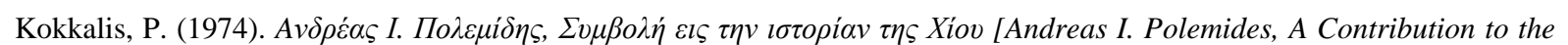
History of Chios] (Vol. 1). Athens: Klapakis.

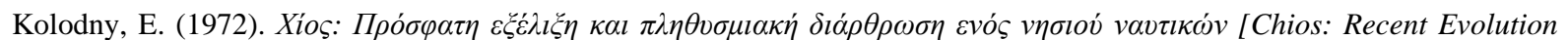
and Population Formation of a Maritime Island] (Translation from the Revue Geographique des pays Mediterraneens N. 8, 1969, Etudes et travaux de "Mediterranee”). Chios: Chiaki Epitheorisi.

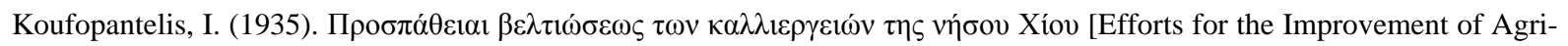
culture in Chios Island]. Avroiov, 1, 33-35.

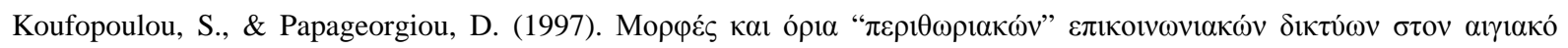

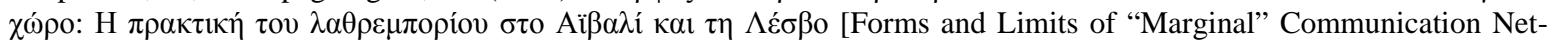
works in the Aegean Space: The Practice of Smuggling in Ayvalic and Lesvos]. Proceedings of the Conference Aiktva

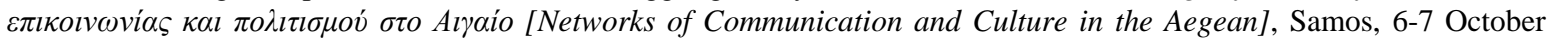
1995, 153-171.

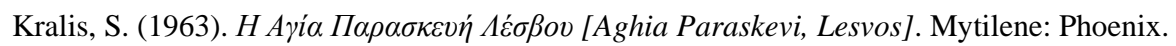

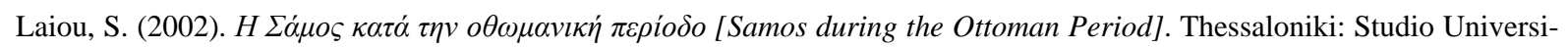
ty Press.

Landros, C. (2002). To $\lambda \alpha \theta \rho \varepsilon \mu \pi$ ó Tobacco Smuggling in Samos and the Ottoman Monopoly Company Regie (1880-1995)]. In M. Vourliotis, \& A. Sfini

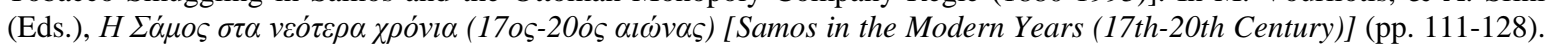
Athens: Adelfotita Samion Athinon.

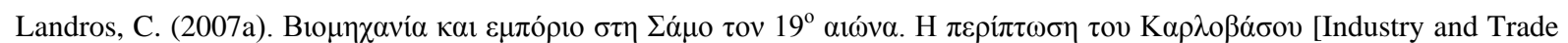

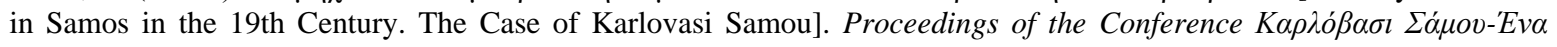

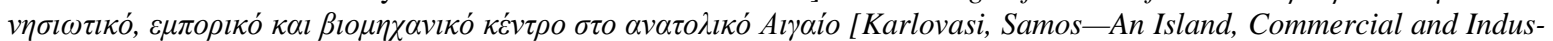
trial Center in the Eastern Aegean], Samos, 15-17 October 2004, 185-196.

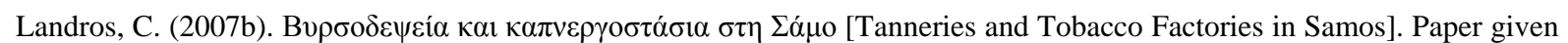

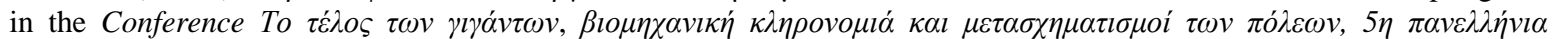

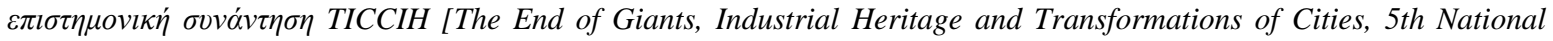
Meeting TICCIH], Volos, 22-25 November 2007.

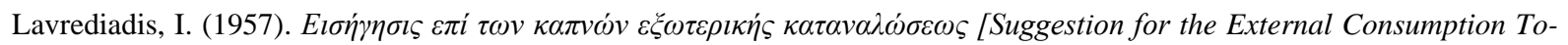
bacco]. Greek Parliament, Period D, Synod B, Committee for Tobacco Issues, Athens: The National Printing House.

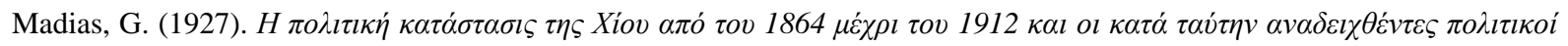
$\dot{\alpha} v \delta \rho \varepsilon \varsigma$ [The Political Situation of Chios from 1864 to 1912 and the Political Men]. Chios.

Matzaroglou, P. (Ed.) (1963). Chios I myrovolos [The Fragrant Chios]. Chios: Prodromos Mantzaroglou.

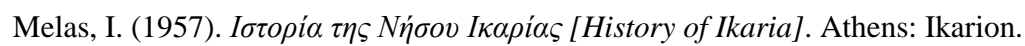

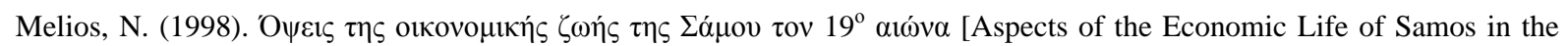

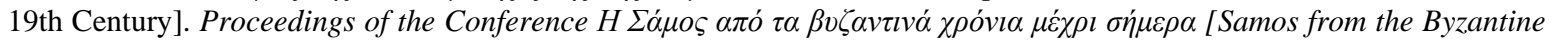
Years up Today], Vol. 2, Samos, 28-30 April 1995, 17-24.

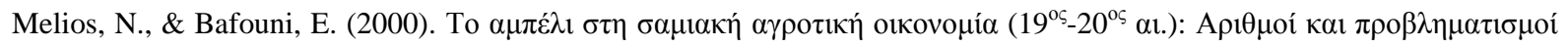
[The Vineyard in Samian Agricultural Economy (19th-20th Century): Numbers and Problems]. In T. Dimitriou (Ed.),

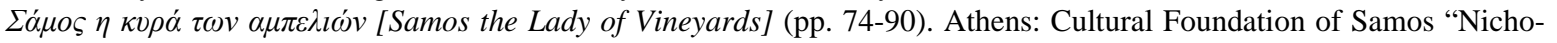
laos Demetriou”.

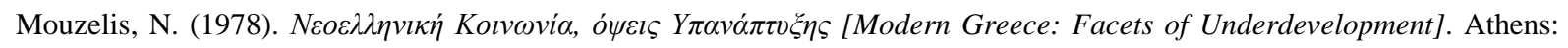
Exandas Publishers.

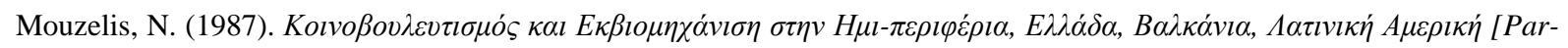
liamentary and Industrialization in the Semi-Periphery, Greece, Balkans, Latin America]. Athens: Themelio Publishers.

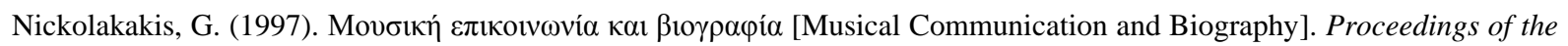

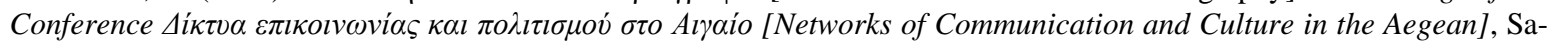
mos, 6-7 October 1995, 125-136.

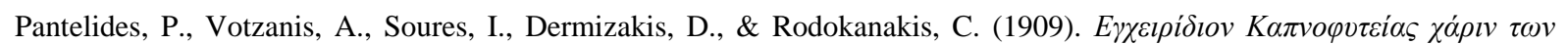
$\gamma \varepsilon \omega \rho \gamma \omega \dot{v} \tau \eta \varsigma$ vं́бov Xiov [A Manual for Tobacco Cultivation for the Farmers of Chios Island]. Chios.

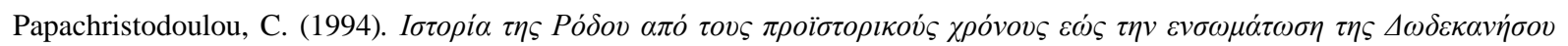
(1948) [The History of Rhodes from the Prehistoric Years up to the Integration of Dodecanese (1948)] (2nd ed.). Athens: Municipality of Rhodes-Stegi Grammaton ke Technon Dodekanisou.

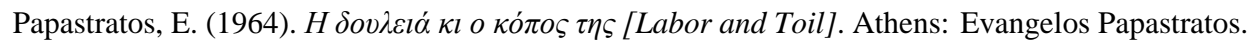




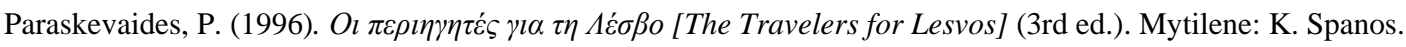

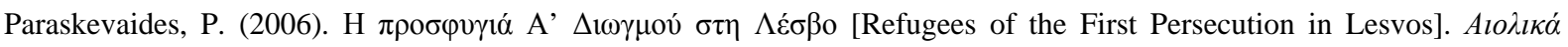
Xоovıко́, 8, 5-160.

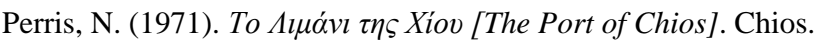

Perris, N. (1972). O Kó $\mu \pi о \varsigma$ [O Kampos, Chios]. Chios: Chaviara BROS

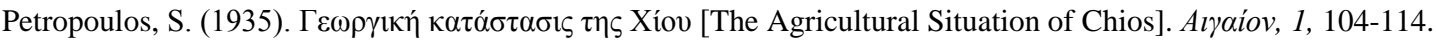

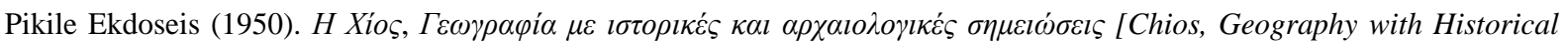
and Archeological Notes]. Chios: N. Kasiotis.

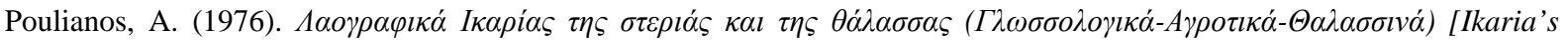
Folklore of Land and Sea (Linguistics-Agriculture-Maritime)] (Vol. I, II \& III). Athens: Eteria Laografikon ke Historikon Meleton Ikarias.

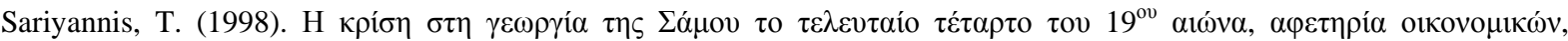

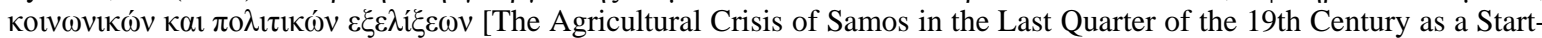

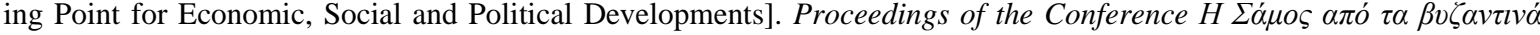

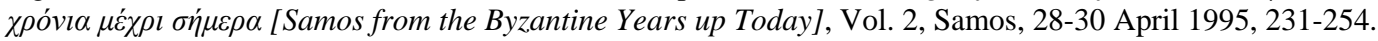

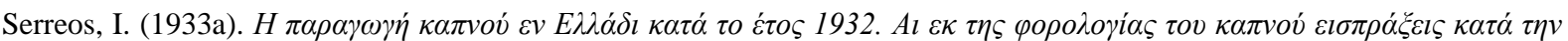

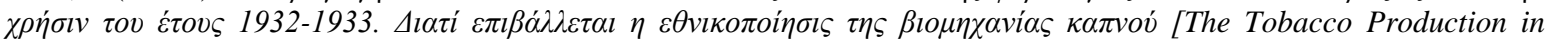
Greece in the Year 1932. The Collections from the Tobacco Taxation during the Crisis of the Year 1932-1933. Why the Nationalization of the Tobacco Industry Is Needed]. Athens: The National Printing House.

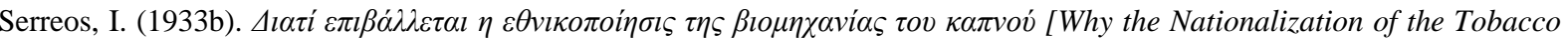
Industry Is Needed]. Athens: The National Printing House.

Sifneos, E. (2005). “Cosmopolitanism” as a Feature of the Greek Commercial Diaspora. History and Anthropology, 16, 97111. http://dx.doi.org/10.1080/0275720042000316641

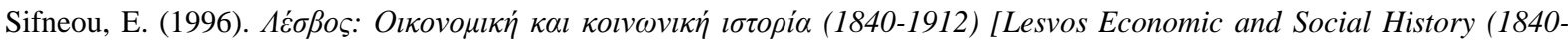
1912)]. Athens: Trochalia.

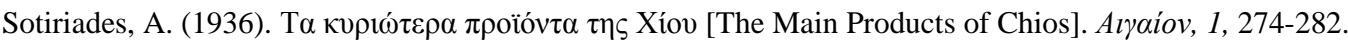

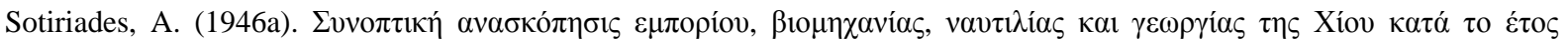

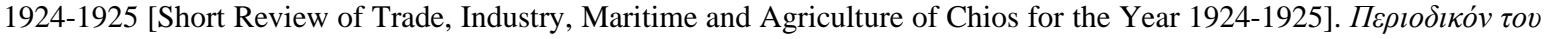

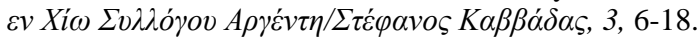

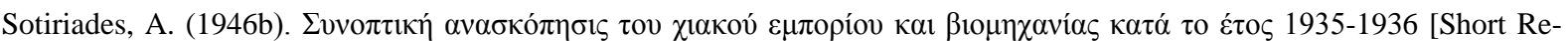

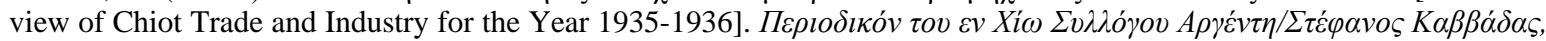
3, 19-39.

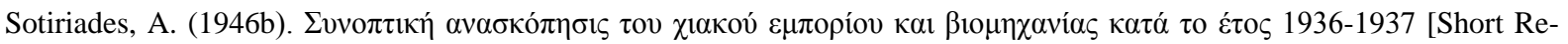

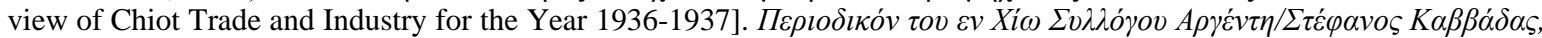
3, 40-54.

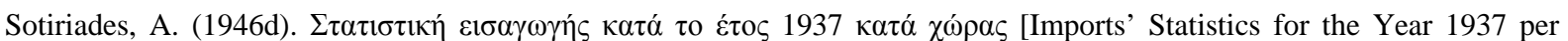

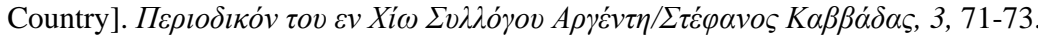

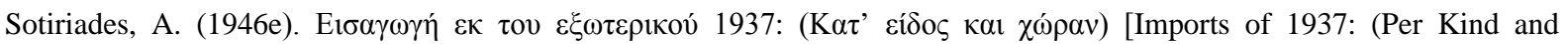

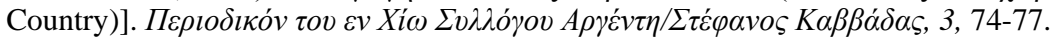

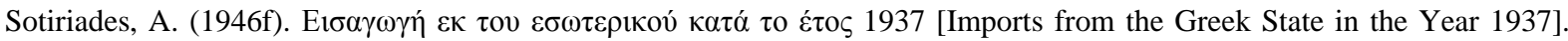

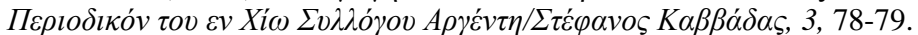

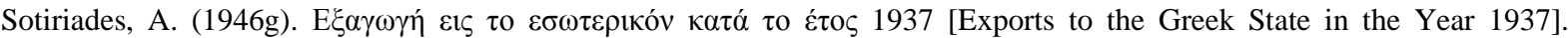

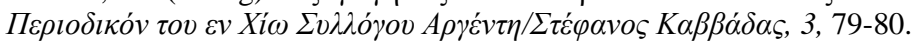

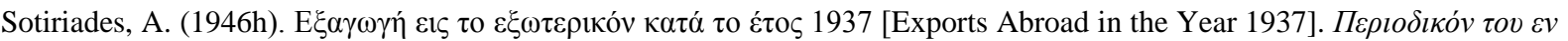

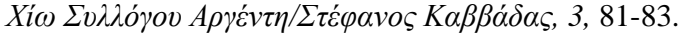

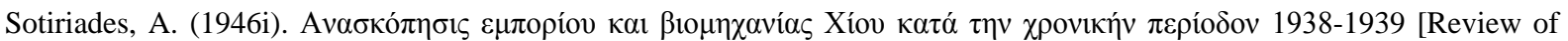

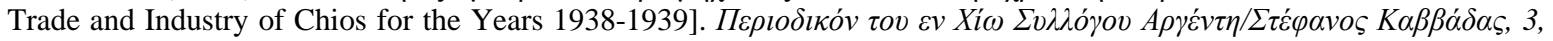
85-101.

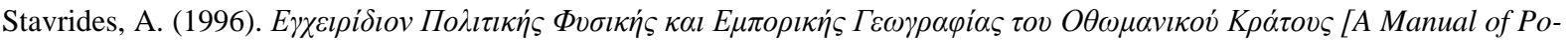
litical, Natural and Commercial Geography of the Ottoman State]. Reprint of the 1876 Edition, V. Anastasiades, \& S. Karavas (Eds.), Mytilene: University of the Aegean.

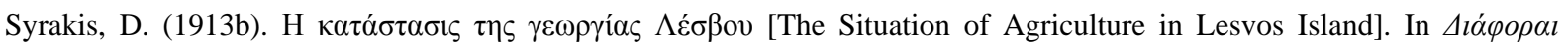

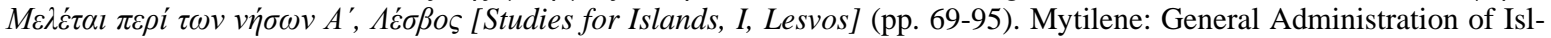
ands. 


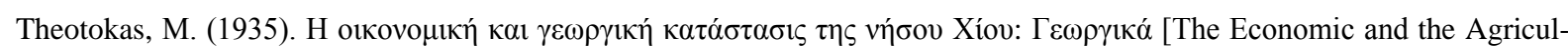
tural Situation of Chios Island: Agriculture]. Alyaiov, 1, 28-33.

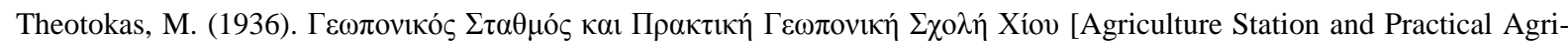
cultural School of Chios]. Alyaiov, 2, 246-252.

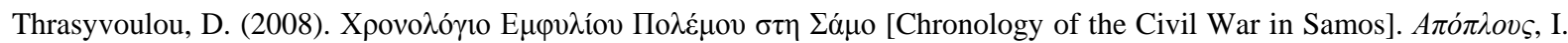
43-44, 270-275.

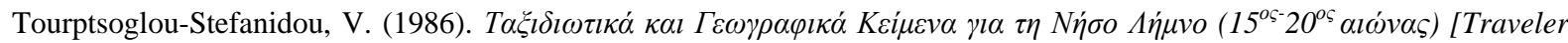
and Geographical Texts for Lemnos Island (15th-20th Century)]. Thessaloniki: Aristotle University of Thessaloniki.

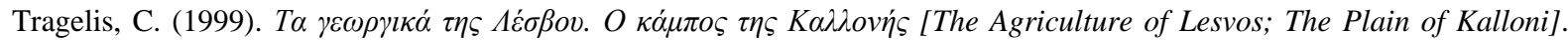
Athens: Municipality of Kalloni.

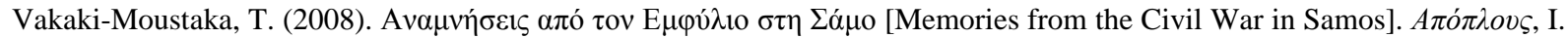
43-44, 402-406.

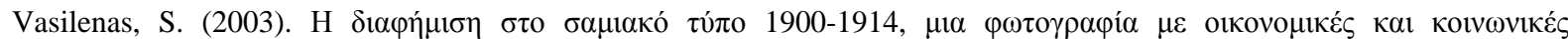

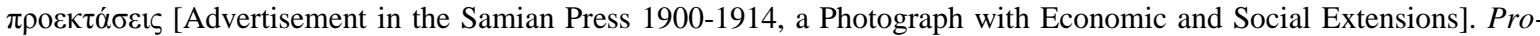

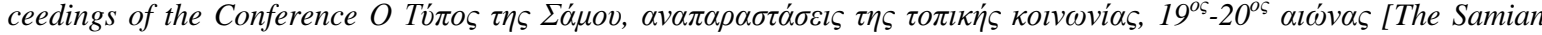
Press, Representations of Local Society 19th-20th Centuries], Samos, 9-10 November 2001, 147-170.

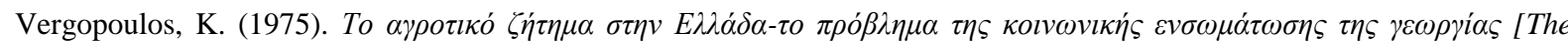
Agrarian Problem in Greece: The Issue of the Social Incorporation of Agriculture]. Athens: Exantas.

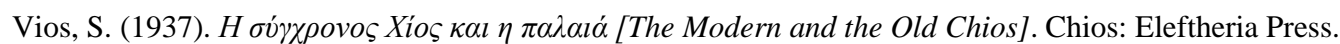

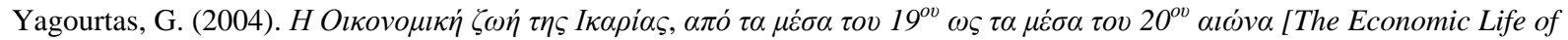
Ikaria from the Middle of the 19th Century up to Middle of the 20th Century]. Athens: Maistros.

Yerolympos, A. (2007). New Patterns of Urban Development in the Aegean Islands, 1850-1920s. In A. Anna Frangoudaki, \& C. Keyder (Eds.), Was to Modernity in Greece and Turkey: Encounters with Europe, 1850-1950 (pp. 236-257). New York: Tauris. 